and the experimental results of Fuoss ${ }^{6}$ and others, produces a decrease of viscosity ; but a nearly complete neutralization of the charge would be required on this basis to give rise to such low viscosities as are observed with 'mustard'-treated nucleic acid. The electrophoretic experiments show that a complete neutralization has not occurred. We conclude, therefore, that these very low viscosities are produced in part at any rate by some other factor. The very low molecular weights observed with the final product suggest that some breakage of the nucleotide chains occurs in the reaction. It is at present uncertain what the molecular weight is immediately after the completion of the reaction, and experiments on this point are being made. A small number of breaks and the consequent reduction of molecular weight of the particles would have a great effect on the viscosity. If the original nucleic acid consists of rod-shaped particles of molecular weight of the order of $10^{6}$, only a few breaks would be required to reduce the viscosity considerably, although other effects of the partial neutralization would also occur.

With regard to the mechanism of such a process, a possibility which is being explored by one of us (W. C. J. R.) is that the tri-substituted phosphate esters produced by reaction with mustard residues of the doubly esterified phosphate groups of nucleic acid are unstable. It has been shown that tri-alkyl phosphates are often less stable than the corresponding di-esters", and that the ease of hydrolysis depends to some extent on the nature of the alcohol component. It may therefore happen that the attachment of a 'mustard' residue to the di-esterified phosphate groups present in nucleic acid may result in a preferential hydrolysis of one of the phosphatesugar links. Experiments are being made on the relative stabilities of di- and tri-phosphate esters derived from radiomimetic compounds to test this hypothesis.

This investigation has been supported by grants to the Royal Cancer Hospital and Chester Beatty Research Institute from the British Empire Cancer Campaign, the Jane Coffin Childs Memorial Fund for Medical Research, the Anna Fuller Fund, and the National Cancer Institute of the National Institutes of Health, U.S. Public Health Service. [Aug. 15.

'Conway, Gilbert and Butler, $J$. Chem. Soc., 3, 421 (1950).

- Butler and James, Nature, 167, 844 (1951).

- Press, E. M., and Butler, J. A. V. (unpublished).

- Creeth, Jordan and Gulland, J. Chem. Soc, 1406 (1949).

- Küh, Künzle and Katschalsky, Helv. Chem. Acta, 81, 1994 (1948).

- e.g., Fuoss and Maclay, J. Polymer Sci., 6, 305 (1951). 'Bailly and Gaumé, Bull. Soc. Chim., 3, 1397 (1936). Plimmer and Burch, J. Chem. Soc., 279
Scand. Chem., 5,23 (i951).

\section{PEOPLE AT WORK}

$\mathrm{T}$

HE sixth Present Question Conference was held at Lady Margaret Hall, Oxford, during April 1950. The theme discussed was "People at Work" and brought together individuals from industry and many other walks of life. A report of the addresses and discussion on this extended form of joint consultation in industry has been published in three successive issues of the journal Question, the last of which has recently appeared.

The first paper was given by John A. Mack, Stevenson lecturer in citizenship in the University of
Glasgow, who discussed the reasons why work has become separated from the rest of life. In primitive societies there is no separate word for work and it is accepted as part of the pattern of living. In industrial communities it is something for which incentives are required, an unnatural condition in a more primitive society; human beings in industry are revolting against a system devised exclusively in response to economic and technical requirements. Originally Mack believed that the root of industrial trouble was in the workers' resentment of arbitrary authority. Investigations in many types of firms have convinced him that this is not so. In one factory where production processes are constantly being changed there is considerable stress, not because of the monotony of mass production, but because of the too frequent absence of monotony; strain is the result of the never-ending sequence of minor changes in machines and operations which results from the continuous ingenuity of technical rearrangement. In this factory there would be little point in changing the inter-personal and inter-group relations unless machine processes are reconstituted so that perscnal strain is eliminated; the machine must be made to fit the man and not man the machine.

This factory example demonstrates the more general conflict between organization and personal integrity in our industrial society. Modern industrial society is activated by two dynamic aspirations. One is to develop the earth's material resources so as to liberate mankind from the curse of poverty. The other is to develop the spiritual resources of the human world by the liberation of personality from the inhibitions of class, and caste, and male domination-from domination and oppression of any kind. The first is partly realized in an economic and industrial system of great ingenuity and power. The second is also realized in part. But the cost of progress has brought the evil of the disruption of what may be called a natural community. Fortunately, people are becoming aware of what is happening and human situations are arising which work against disruption.

In the second address Dr. J. H. Oldham considered the theme of industry and modern society. To-day, it is recognized that our technical, industrial society is involved in a fundamental crisis. The values in which men have believed and lived by for two thousand years have, for an increasing number of people, lost their authority and power of appeal. Industry, too, is involved in a crisis, and has to face the question whether an industrial society can produce and nourish the human qualities which are needed for maintaining society in a state of health. No technical advances, no improvements in organization, not even greater justice in the distribution of the proceeds of industry, will avail anything if the human material on which, in the last resort, everything depends, is inferior in quality. The crisis in which society and industry are alike involved to-day is fundamentally a crisis of men. Industry cannot solve its own problem unless the other forces in society are working in the right direction and lend it support; society cannot solve its crucial problem unless industry plays its part in that solution.

The fundemental cause of the crisis both in society and industry lies in the belief that the whole of life can be mastered by human understanding and that everything is calculable. Man's triumph over Nature has become his enslavement-the enslavement of man to apparatus, technics, mechanization, 
organization, the division of labour and centralization. In industry this has been carried to its furthest limits, and economic and technical considerations have ruled out the consideration of man as a human and social being. With Prof. Rosenstock-Huessy, Oldham agrees that the working of the shift system and payment by the hour are both practices which sever man's work from his personal life. The fundamental problem is to find a place for man in an industrial and economic order inescapably subject to technical requirements and natural laws. Man must be helped to gain his self-respect and his sense of relationship, and industry has an indispensable part to play in this re-creation. Happily there is increasing evidence that industry is becoming aware of its human responsibilities and in some ways is already beginning to work out a type of society which is neither individualistic nor collectivist but social, and in which it is accepted that human values are more important than the technical.

Sir Wilfrid Garrett considered the role of work as education, and at first discussed the effects of his first job in industry on a boy who has recently left school. According to Sir Wilfrid the boy finds himself in an environment where he is required to serve a purpose irrespective of what he feels he wants. To help the boy in his confusion industry has to break up its often vague largeness into manageable parts which can be grasped by the individual ; the production managers have to realize that they are dealing with human beings. In the case of the young people themselves they should be made to feel that however small a part they play in the industrial machine it is never without meaning because it always serves the good of the community.

Work is also teaching industrial workers at all levels the value of co-operation; and, while there may be need for less craftsmanship in industry, men and women in charge of complicated machines are proud of their charge and the products they produce in relation to the whole. Sir Wilfrid also described the educative value of various training schemes in industry and those organized for industrial workers by such organizations as the Outward Bound Trust, Brathay Hall, and the Young Men's Christian Association.

$\mathrm{He}$ was followed by Sir George Schuster on the theme of human relations and production, who stated that what is chiefly needed is the application of already existing ideas; the main practical problem is to get those unprogressive elements in British industry - about 90 per cent-to accept the principles and practices of the others. In the nationalized industries, particularly, the study of human relations should be regarded as a matter of vital importance : in general, one of the grave issues of the post-war world is the moral disintegration which has affected other countries in Europe more than Britain. Another difficulty is that the workers still carry bitter memories of their oppression over a period of more than a hundred years. Nor has educational develop. ment kept in step with material development. With Rostovtzeff, Sir George speculates whether it is possible to extend a higher civilization to the lower classes without debasing its standard and diluting its qualities to the vanishing point? "Is not every civilization bound to decay as soon as it begins to penetrate the masses ?" Britain has not yet evolved a satisfactory pattern of an educated and democratic industrial society. If human relations in industry are to be satisfactory, three essential conditions must be fulfilled. First, each individual must be treated as an end in himself, and not as a means to an end. Secondly, he must be given the basis for the good life, including his status in society. Thirdly, the individual must recognize that he can only realize himself satisfactorily as a member of a community. Nor can any man lead a good life unless he is doing a good job of work despite those conflicting loyalties born of an industrial society. Here joint consultation properly interpreted is an essential condition for establishing the right kind of human relationships in industry. Nor can 'loyalty' be expected unless the individual really accepts the belief that he 'belongs' to the firm.

Prof. C. A. Mace considered under what conditions work may be made not only more effective but also a source of greater satisfaction to those who do it. In general, work is not attractive or repulsive because of any particular feature in isolation; it depends upon the pattern of the work as a whole. It is not repetition or variety that matters but the ratio of repetition to variety. Everyone needs the element of adventure or risk against a background of fundamental security. In industry to-day there is a lack of balance. a lack of individuality, the worker feeling deprived of the sense of responsibility for an individual task. The new industrial order can be created only by slow progressive stages, taking each job one by one, and by the gradual development and application of new principles, new policies and new procedures of management. Sufficient evidence is already available to show that sub-division, standardization and simplification have been overdone and that efficiency and satisfaction in the job will be enhanced by a reversal of these trends.

To help in understanding how people work in industrial societies, Prof. S. F. Nadel addressed the conference on work in relatively simple, pre-industrial and pre-literate societies. In these primitive societies men mostly work on their own, the typical use of capital, whereby certain individuals pay for the services and efforts of others, being largely unknown. Nor, in primitive societies, do people work so that they may enjoy pursuits out of work ; their enjoyments are often so directly connected with the work and its results that the completion of the job,.its reward, and the desired enjoyments merge into one.

One important and widespread incentive in primitive societies lies in the work itself. In settled agricultural communities the people always attach great importance to the attractive lay-out of the farms ; anthropologists have long been struck by the great importance of display in primitive economy, the chance of displaying success probably acting as the strongest incentive to work. Behind the activity of most individuals is the wish to attain prestige or to win the admiration and approval of others. In other societies where there is a choice of work, like weaving or leatherwork, the individual conceives of his work as being in some measure the concern of supernatural powers. For each individual work is a duty which he does not question, rooted in religious belief and buttressed by the idea that it has been vested in his family or line of descent since times immemorial. For primitive man work may be regarded as a 'passport', if not to social excellence, at least to the fulfilment of an ethical or religious code.

In discussing motivations and the effects of motiva. tion on productivity, Mrs. Winifred Raphael suggested that productivity is an attitude of mind. When there is not a strong motivation to work, there is 
poor output and high labour wastage; there is also boredom and discontent. Whether a person is bored or interested in his work depends upon whether he is properly suited to that work; some people are suited by supervisory jobs, and others are most happy when doing apparently dull, routine, mechanical jobs. To be properly suited all individuals should be helped to find the right job when they leave school and, later, in any change they make; and, when labour is short, it is most important to use the labour force to the best advantage. It was Sir Walter Raleigh who said, "The nightingale did not win a prize in the poultry show"; a real attempt must be made to match the person to the job and the job to the person. Boredom or interest will also depend upon the extent to which the individual participates in the affairs of the firm; this may be encouraged by formal and informal joint consultation. Interest also depends upon the social environment and, for many people in industry, what matters most is neither the job nor the pay but the people they are working with; workers' solidarity is one of the strongest motives in industry.

Probably, however, the greatest effect upon motivation depends upon whether an individual feels he is being fairly treated; pay is always thought of in relation to other individuals. Another factor affecting motivation for or against work is whether individuals are repressed or encouraged; pride in the job is an important incentive. Training is also important since the individual feels that opportunities for training may lead to promotion.

After discussing motivating forces in general, Mr. E. W. Hughes advocated the use of intelligent rather than sentimental control of the prime urges to action. Among the more permanent incentives he regarded the need to satisfy self-expression through some activity as one of the most important, especially if the effort is recognized by the group in terms accepted by the group. Mr. Hughes has had special experience in the mining industry, and here, although many motivation problems are similar to those of other industries, the industry still has a long leeway to make up in certain conditions of work. But the effort is being made, and the National Coal Board is making a genuine and not unsuccessful attempt to remove factors which cause accidents, the stigma which goes with dirty faces and dirty clothes, and other deterrents. At Keresley Colliery, near Coventry, for example, the surface lay-out is such that, but for the pit-head gear, the colliery could be mistaken for a light engineering factory. In South Wales the casualties caused by dust resulted in a drift from the industry. The dust problem has been energetically tackled, and miners are returning to the industry.

Among the reasons why people enter the coal. mining industry is security of tenure. This is particularly true of young men and, for them, various apprenticeship and training schemes have been devised. Good wages have not the incentive value usually described, as is shown by the reduction of the mining labour force despite considerable increases in pay. Mr. Hughes also expressed the need for an extended system of joint consultation at horizontal levels in the mining industry.

In his address on organization and the person Mr. R. W. Latham suggested that joint consultation is not consultative procedure but an attitude of mind. Nor is it new despite the official introduction of joint consultation to industry by Sir Stafford Cripps in
1942 ; some small firms in Britain had established machinery for joint consultation in the eighteenth century. Mr. Latham also pleaded for the use of ad hoc committees in those departments of a factory which have particular problems. But he could not agree with other speakers who believed that, apart from wages negotiations, confidential matters to the firm and about individuals, nothing should be barred from discussion at works councils. According to Latham, most workers do not understand balance sheets or market research, and he advocated the education of industrial employees as one of the most urgent needs of to-day; this should be undertaken by the trade unions themselves. The majority of workers do want to participate in the activities of their firm, but, despite the clamour of a small minority, they do not want control.

In the ensuing discussion probably the most interesting point which arose concerned the profit motive and the social purpose of industry. This was summarized by one speaker as consisting of three main factors : first, it is generally accepted that private industry cannot be allowed to follow its own way without an ethical code ; secondly, bureaucratic control is bad for industry because it is so negative; thirdly, there is a considerable and justifiable demand for participation in the control of industry and responsibility for running it by all who are engaged in it.

T. H. HAWKINS

\section{INDUSTRIAL RADIOLOGY GROUP OF THE INSTITUTE OF PHYSICS}

\section{SUMMER MEETING}

$T$ HE summer meeting of the Industrial Radiology Group of the Institute of Physics was held at the Institute's House, 47 Belgrave Square, London, S.W.1, during July 23-25. A programme of lectures, covering a wide field of interest to the industrial radiologist, was arranged. One of the most interesting was that by Mr. L. van Ouwerkerk (Röntgen Technische Dienst, Holland), with the title "Xeroradiography", which it was explained is a dry method without the use of photographic films and is at present in the laboratory stage.

Mr. van Ouwerkerk stressed that his was largely a report of what had been done in the United States on this subject. Starting with a description of the application of xerography to photography, he described how a layer of photo-conducting insulating material, deposited on a metal plate, is charged and then exposed to light, with the resultant leaking away of the charge in proportion to the light falling on any spot. This latent image is developed by dusting with a fine powder which adheres only where the plate is charged. Prints can be made by transferring and fixing the powder image to paper. In elaborating these points Mr. van Ouwerkerk described in detail the requirements of the photo-sensitive plate as regards electrical conductivity and how it is charged under corona discharge, as well as the action of incident light in discharging it. He said that the latent image can be retained on the plate for several days, and described how it is developed by a powder mixture consisting of a fine resinous powder and a granular carrier of relatively large particle size, which serves to generate a charge on the smaller powder particles. 